\title{
Glucosamine, a naturally occurring amino monosaccharide, inhibits A549 and H446 cell proliferation by blocking $\mathrm{G1} / \mathrm{S}$ transition
}

\author{
YINGHUA JU, AIMING YU, XIUHUA SUN, DIDI WU and HONGKAI ZHANG \\ Department of Biochemistry and Molecular Biology, College of Basic Medical Sciences, \\ China Medical University, Shenyang, Liaoning 110001, P.R. China
}

Received February 4, 2013; Accepted July 2, 2013

DOI: $10.3892 / \mathrm{mmr} .2013 .1584$

\begin{abstract}
Uncontrolled proliferation is important in tumorigenesis. In the present study, the effects of glucosamine on lung cancer cell proliferation were investigated. The expression of cyclin $\mathrm{E}$, one of the key cyclins in the G1/S transition, and Skp2, the ubiquitin ligase subunit that targets the negative cell cycle regulator, $\mathrm{p} 27^{\mathrm{Kip} 1}$, were also assessed. Moreover, the underlying mechanisms of action of glucosamine were investigated in lung cancer cells. A549 and H446 cells were synchronized using thymidine in the presence or absence of glucosamine. The effect of glucosamine on lung cancer cell proliferation was determined by MTT assay. Cyclin E and $\mathrm{p} 27^{\mathrm{Kip} 1}$ proteins and their phosphorylation levels were detected by western blot analysis. Furthermore, the effect of glucosamine on the cell cycle was evaluated by flow cytometry. Glucosamine was found to inhibit lung cancer cell proliferation and to suppress Skp2 and cyclin E expression. Notably, the phosphorylation levels of cyclin E (Thr62) and p27 Kip1 (Thr187) were downregulated by glucosamine, and negatively correlated with degradation. Glucosamine was also found to arrest lung cancer cells in the G1/S phase. Thus, glucosamine may inhibit lung cancer cell proliferation by blocking G1/S transition through the inhibition of cyclin E and Skp2 protein expression.
\end{abstract}

\section{Introduction}

Glucosamine, a naturally occurring monosaccharide, acts as a preferred substrate for the biosynthesis of glycosaminoglycan and has been used for the treatment of osteoarthritis for $>2$ decades (1). Furthermore, glucosamine has been shown to

Correspondence to: Dr Yinghua Ju, Department of Biochemistry and Molecular Biology, College of Basic Medical Sciences, China Medical University, 92 Second North Road, Shenyang, Liaoning 110001, P.R. China

E-mail: yinghua_423@hotmail.com

Key words: glucosamine, lung cancer, cyclin E, $O$-linked $\mathrm{N}$-acetylglucosamine modification inhibit neutrophil functions, including superoxide generation, phagocytosis, granule enzyme release, chemotaxis and CD11b expression, thereby possibly exhibiting an anti-inflammatory action $(2,3)$. Glucosamine was recently reported to inhibit intercellular adhesion molecule-1 (ICAM-1) and monocyte chemoattractant protein-1 (MCP-1) expression in human umbilical vein endothelial cells (HUVECs), thus showing anti-atherosclerotic activities (4,5). A number of studies have reported that glucosamine has an additional biological function, whereby it inhibits tumor growth in vivo and in vitro $(6,7)$. Wang et al (8) reported that the glucosamine sulfate-induced apoptosis of leukemia K562 cells is associated with the translocation of cathepsin $\mathrm{D}$ and downregulation of Bcl-xL. Another study has shown that D-glucosamine inhibits the proliferation of human cancer cells through inhibition of p70S6K (9). Although the study attempted to investigate the mechanisms underlying this antitumor effect, the exact mechanism remains to be fully elucidated. The regulation of cell cycle checkpoints is important for the proper transition from one phase of the cell cycle to the next. In particular, the regulation of the G1 switching mechanisms between quiescence and proliferation is defective in cancer cells, allowing them to continuously grow $(10,11)$. Cyclin E levels reach a peak in the G1 phase, while cyclin E is rapidly degraded during the early $\mathrm{S}$ phase. Cyclin $\mathrm{E}$ expression and, consequently, cyclin E/CDK2 activity is closely associated with the G1/S checkpoint (12). Various studies have indicated that cyclin $\mathrm{E}$ is overexpressed in several tumor cells, such as breast cancer cells, and it has been reported to be a prognostic biomarker $(13,14), \mathrm{p} 27^{\mathrm{Kip} 1}$ is one of the most important cell cycle regulatory proteins. The Skp2-induced ubiquitylation of $\mathrm{p} 27^{\mathrm{Kip} 1}$ results in the recruitment of $\mathrm{p} 27^{\mathrm{Kip} 1}$ to the Skp1pcullin-F-box protein (SCF) core complex, but only after $\mathrm{p} 27^{\mathrm{Kip} 1}$ is phosphorylated on Thr187, a step that is required for Skp2 to recognize $\mathrm{p} 27^{\mathrm{Kip}}$. The important role of Skp2 in promoting entry into the $\mathrm{S}$ phase, mainly by promoting p $27^{\mathrm{Kip} 1}$ destruction, has been demonstrated in both cell-free systems and cell cultures (15). Low levels of $\mathrm{p} 27^{\mathrm{Kip} 1}$ have been found to markedly impact tumor progression and accurately predict poor prognosis in a large variety of cancers, including breast, colorectal and prostate carcinomas, as well as other epithelial carcinomas, sarcomas and hematological malignan- 
cies $(15,16)$. These studies have suggested that loss of $\mathrm{p} 27^{\mathrm{Kip}}$ contributes to uncontrolled tumor proliferation.

In the present study, the effects of glucosamine on lung cancer cell proliferation, as well as on cyclin E and Skp2 expression levels were investigated. Cyclin E and Skp2 were found to be overexpressed in the lung cancer cell lines A549 and H446, indicating an association with lung cancer. Furthermore, glucosamine was shown to inhibit cyclin E and Skp2 expression in these cell lines. Therefore, this study suggests that glucosamine may inhibit lung cancer cell proliferation by blocking G1/S transition through the inhibition of cyclin E and Skp2 protein expression.

\section{Materials and methods}

Reagents. D-glucosamine hydrochloride was purchased from Sigma-Aldrich (St. Louis, MO, USA).

Analysis of cyclin E and Skp2 protein expression and their phosphorylation levels by western blotting. Cells at $80 \%$ confluency were incubated with $2 \mathrm{mM}$ thymidine for $16 \mathrm{~h}$. The medium was then changed to normal medium and the cells were cultured for $9 \mathrm{~h}$, followed by an additional culture with $2 \mathrm{mM}$ thymidine for $16 \mathrm{~h}$. Various concentrations of glucosamine $(0.1-5 \mathrm{mM})$ were used in this study. To detect the phosphorylation levels of cyclin E, thymidine-synchronized cells were released into normal medium with or without $1 \mathrm{mM}$ glucosamine and cultured for $1.5 \mathrm{~h}$. The cells were recovered in $250 \mu \mathrm{l}$ of lysis buffer $(10 \mathrm{mM}$ Tris- $\mathrm{HCl}, \mathrm{pH} 7.4,1 \%$ Triton $\mathrm{X}-100,100 \mathrm{mM} \mathrm{NaCl}, 0.5 \%$ sodium deoxycholate, $1 \mathrm{mM}$ EDTA, $1 \mathrm{mM}$ EGTA and $1 \mathrm{mM}$ di-isopropyl fluorophosphate) containing 1:25 v/v Complete ${ }^{\mathrm{TM}}$ (Roche Diagnostics, Mannheim, Germany). The cells were not synchronized for the detection of Skp2, since Skp2 is expressed throughout the cell cycle. Cell lysates were placed on ice for $30 \mathrm{~min}$ and centrifuged at $14,000 \mathrm{x}$ g for $10 \mathrm{~min}$. The supernatants were recovered, and samples (10 $\mu \mathrm{g}$ protein/lane) were subjected to $10 \%$ sodium dodecyl sulfate (SDS)-polyacrylamide gel electrophoresis (PAGE). Separated proteins were transferred to polyvinylidene difluoride (PVDF) membranes (Millipore Corporation, Bedford, MA, USA). The membranes were blocked with $5 \%$ skimmed milk and probed with rabbit anti-human cyclin E, p27 ${ }^{\mathrm{Kip} 1}$ polyclonal antibody or rabbit anti-human phospho-cyclin E (Thr62), phospho-p27 ${ }^{\text {Kip1 }}$ (Thr 187) polyclonal antibodies, respectively (Cell Signaling Technology, Beverly, MA, USA). After washing with phosphate-buffered saline (PBS) with $0.05 \%$ Tween 20 , the membranes were further probed with horseradish peroxidase (HRP)-conjugated goat anti-rabbit IgG (Chemicon International, Temecula, CA, USA), and the target bands were finally detected with a the chemiluminescent substrate luminol (Pierce, Rockford, IL, USA). The detected bands were quantified using a GIS-1000 image analyzer (Fujitsu, Tokyo, Japan). The antibodies were then stripped from the membranes using Restore Western Blot stripping buffer (Pierce). GAPDH in each sample was detected using mouse anti-GAPDH monoclonal antibody (MAB374; Chemicon International) and HRP-conjugated goat anti-mouse $\mathrm{IgG} / \mathrm{IgM}$ (Chemicon International). The protein content was determined with a BCA protein assay kit (Pierce).
MTT assay. Cell viability was assayed using the CellTiter $96^{\circledR}$ aqueous one solution cell proliferation assay (Promega, Medison, WI, USA) according to the manufacturer's instructions. Briefly, the cells were detached with trypsin and collected in $10 \mathrm{ml}$ of complete medium. Cells $\left(2 \times 10^{3}\right)$ in a $90-\mu 1$ volume were aliquoted in triplicate into each well of a 96 -well plate. After $18 \mathrm{~h}, 10 \mu \mathrm{l}$ of medium containing $0.1-5 \mathrm{mM}$ concentrations of glucosamine was added to each well and incubated for $24 \mathrm{~h}$. Then, $20 \mu \mathrm{l}$ of a mixture containing phenazine methosulfate in 3-(4,5-dimethylthiazol-2-yl)-5-(3-carboxymethoxyphenyl)-2-(4-sulfophenyl)-2H-tetrazolium, inner salt (MTS) and phenazine ethosulfate was added to each well. The plates were incubated at $37^{\circ} \mathrm{C}$ in $5 \% \mathrm{CO}_{2}$ for $80 \mathrm{~min}$. Formazan product was detected by measuring the absorbance at $490 \mathrm{~nm}$. Percent growth inhibition (\% GI) was calculated according to the following formula: $100 \times(\mathrm{T}-\mathrm{T} 0) /(\mathrm{C}-\mathrm{T} 0)$, where $\mathrm{T}$ is the absorbance of the test well after $72 \mathrm{~h}$ of exposure to test chemicals, T0 is the absorbance at time zero and $\mathrm{C}$ is the control absorbance.

Flow cytometry. For flow cytometric analysis of the DNA content, $\sim 10^{6}$ cells were fixed in $80 \%$ ethanol at $-20^{\circ} \mathrm{C}$ for $24 \mathrm{~h}$. Ethanol-fixed cells were stained with propidium iodide (PI) staining solution $(20 \mu \mathrm{g} / \mathrm{ml} \mathrm{PI,} 0.1 \mathrm{mg} / \mathrm{ml}$ RNase A, 0.1\% NP-40 and $0.1 \%$ trisodium citrate) for $30 \mathrm{~min}$, and then analyzed using a FACS analyzer (BD Labware, Franklin Lakes, NJ, USA).

\section{Results}

Glucosamine inhibits lung cancer cell proliferation. To evaluate the effect of glucosamine on lung cancer cell proliferation, A549 and H446 cells were incubated with various concentrations of glucosamine for $36 \mathrm{~h}$. As shown in Fig. 1, glucosamine inhibited cell proliferation in a dose-dependent manner.

Glucosamine treatment arrests cell cycle in the G1 phase. Cell cycle progression is disordered in cancer cells, and the inhibition of cell proliferation is important in cancer therapy (16). Therefore, we detected the effect of glucosamine on cell cycle progression. Glucosamine treatment altered lung cancer cell cycle progression (Figs. 2 and 3). More specifically, the number of thymidine-synchronized H446 cells arresting in the G1 phase was increased by $\sim 6 \%$, and the number of normally cultured H446 cells in the G1 phase was increased by $14 \%$ (Fig. 2). Similar results were found in A549 cells (Fig. 3).

Cyclin E and Skp2 are overexpressed in lung cancer cells. The accumulation and degradation of cyclin E and Skp2 are important for G1/S transition. Previous research has shown that cyclin E and Skp2 are overexpressed in various cancer cells and tissues $(12,16)$. Therefore, cyclin E and Skp2 protein levels in the lung cancer cell lines A549 and H446 were investigated. As expected, cyclin E and Skp2 were overexpressed in these lung cancer cell lines compared with MRC-5 cells (human embryonic lung cells), indicating an association between cyclin E/Skp2 levels and lung cancer (Fig. 4).

Glucosamine inhibits Skp2 and cyclin E expression. The effect of glucosamine on cyclin E and Skp2 expression in the lung cancer cell lines A549 and H446 was evaluated. As shown in Fig. 5, glucosamine inhibited cyclin E and Skp2 expression in a 
A

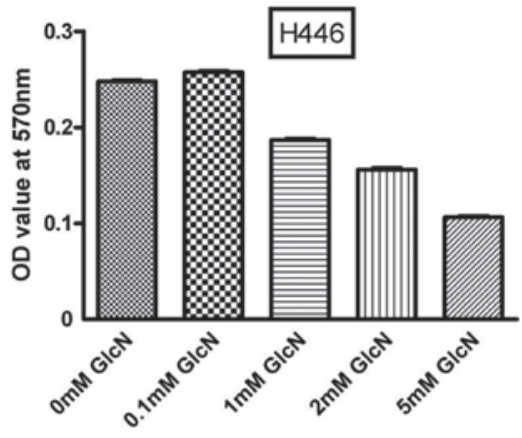

B

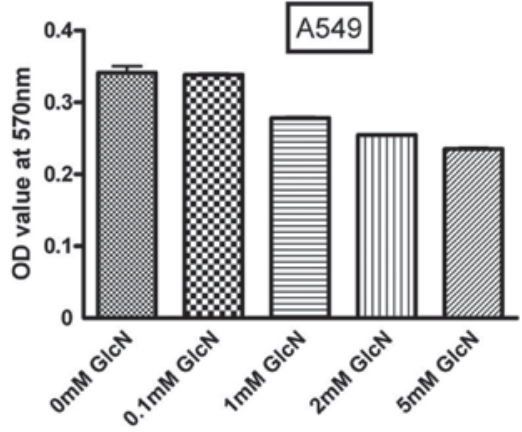

Figure 1. Effect of glucosamine $(\mathrm{GlcN})$ on $\mathrm{A} 549$ and $\mathrm{H} 446$ cell proliferation A549 and H446 cells at $~ 80 \%$ confluency were incubated without or with glucosamine (0.1-5 mM) for $36 \mathrm{~h}$. Cell viability was detected using an MTT assay.
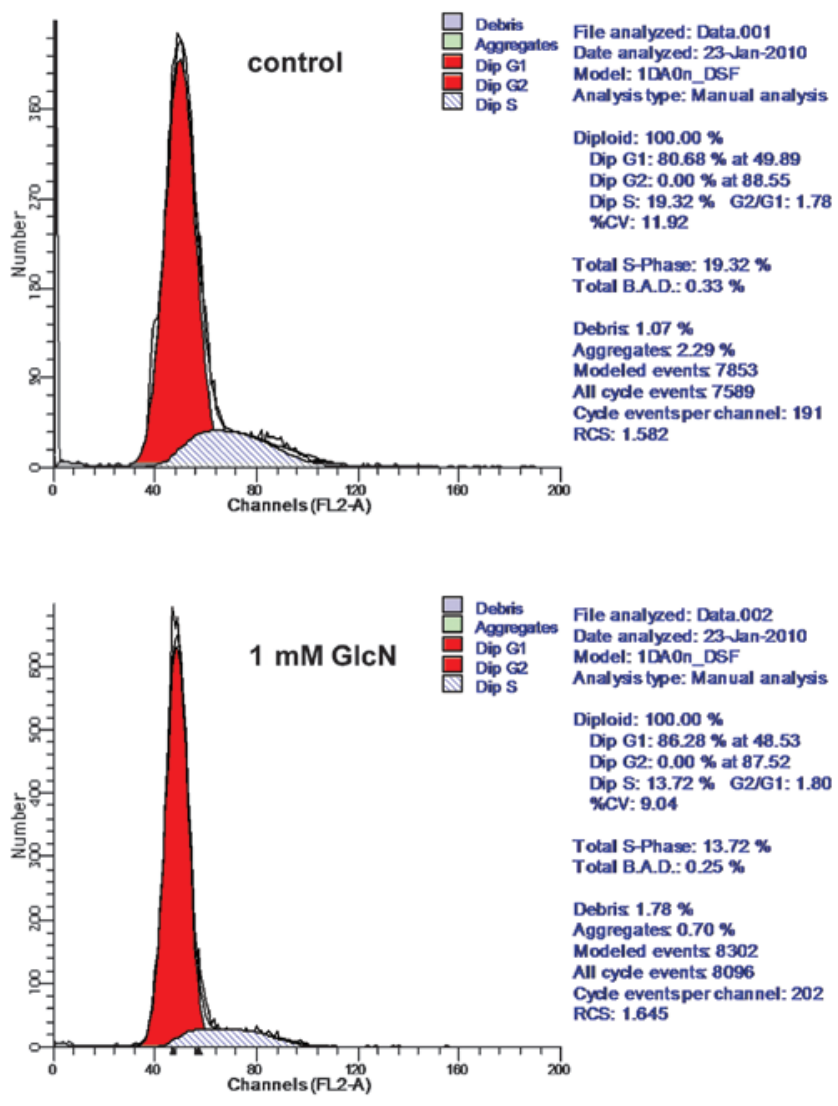

Figure 2. Effect of glucosamine $(\mathrm{GlcN})$ on the cell cycle of $\mathrm{H} 446$ cells. $\mathrm{H} 446$ cells at $\sim 80 \%$ confluency were incubated without or with glucosamine $(1 \mathrm{mM})$ for $24 \mathrm{~h}$. The cells were harvested, and the DNA was then isolated and analyzed using a FACS analyzer.
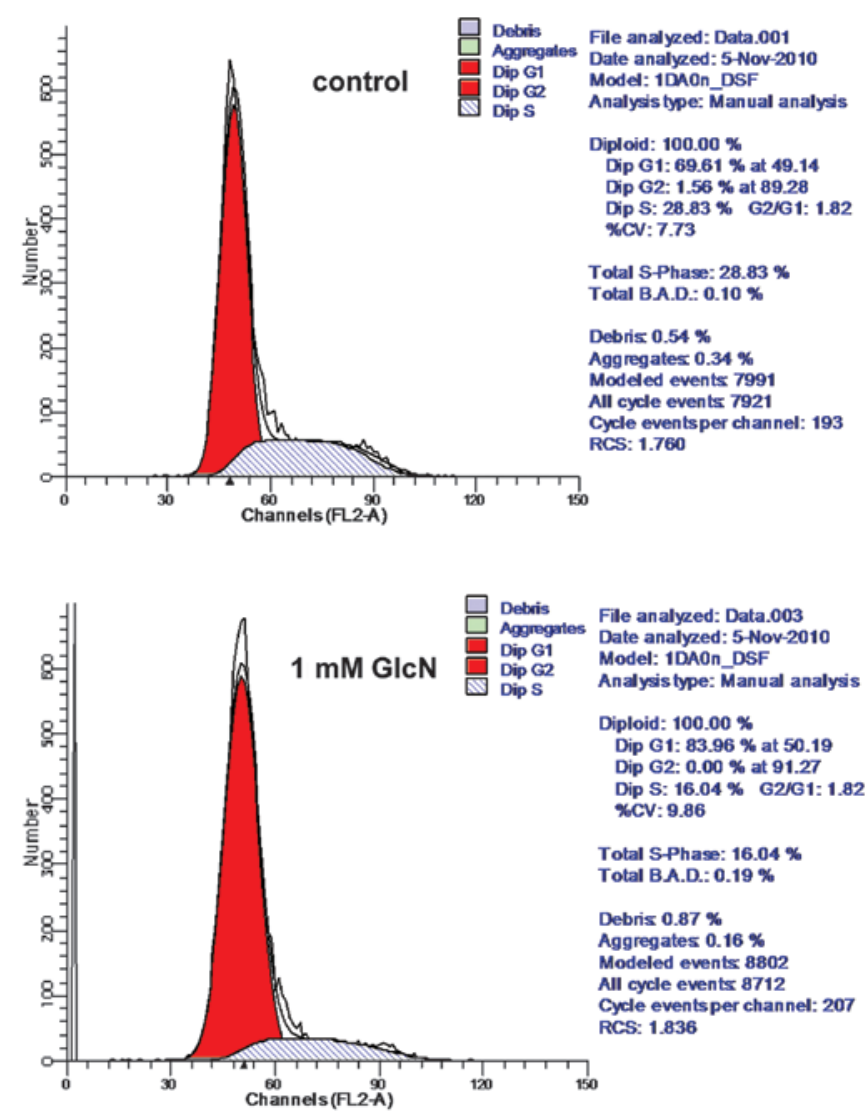

Figure 3. Effect of glucosamine $(\mathrm{GlcN})$ on the cell cycle of A549 cells. A549 cells at $\sim 80 \%$ confluency were incubated without or with glucosamine $(1 \mathrm{mM})$ for $24 \mathrm{~h}$. The cells were harvested, and the DNA was then isolated and analyzed using a FACS analyzer.

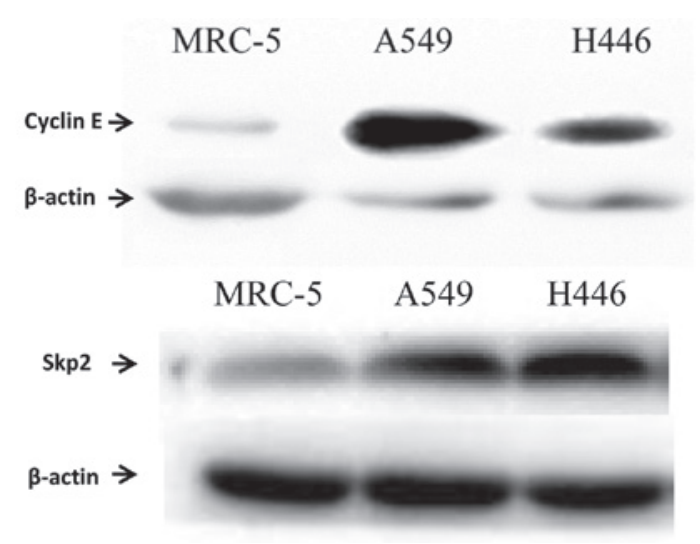

Figure 4. Cyclin E and Skp2 expression in A549, H446 and MRC-5 cells. A549 and H446 cells were synchronized in the G1 phase using $2 \mathrm{mM}$ thymidine. Cyclin E protein levels were determined by western blot analysis. For the determination of Skp2 protein levels, the cells were not synchronized, since Skp2 is expressed throughout the cell cycle.

dose-dependent manner, indicating a potential inhibitory effect of glucosamine on lung cancer cell proliferation. The same inhibitory effect was observed in H446 cells (data not shown).

Glucosamine inhibits cyclin $E$ degradation via cyclin $E$ phosphorylation. Cyclin E is important in G1/S transition. Glucosamine was found to inhibit cyclin E Thr62 phosphory- 

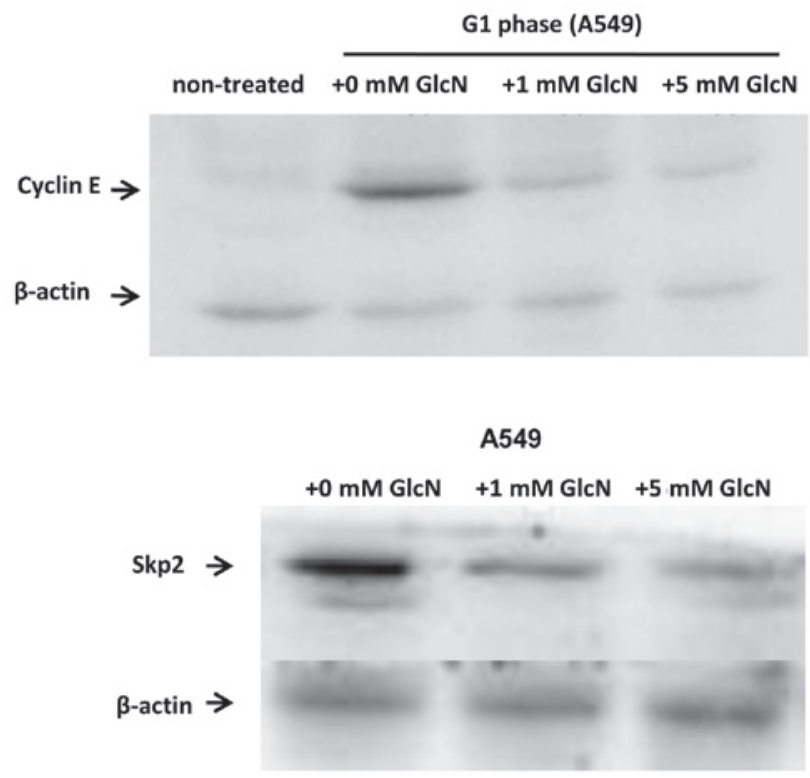

Figure 5. Effect of glucosamine on cyclin E and Skp2 expression. A549 cells were synchronized with $2 \mathrm{mM}$ thymidine and cultured without or with glucosamine (GlcN). Cell lysates were recovered and the cylin E protein level was detected by western blot analysis. For the determination of Skp2 protein levels, the cells were not synchronized, since Skp2 is expressed throughou the cell cycle.

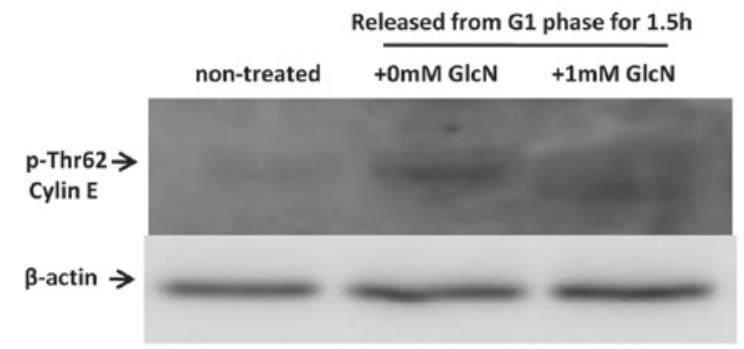

Figure 6. Effect of glucosamine on cyclin E phosphorylation. A549 cells were synchronized in the G1 phase and then released into normal medium with or without glucosamine (GlcN; $1 \mathrm{mM})$ for $2 \mathrm{~h}$. The phosphorylation level was detected by western blot analysis.

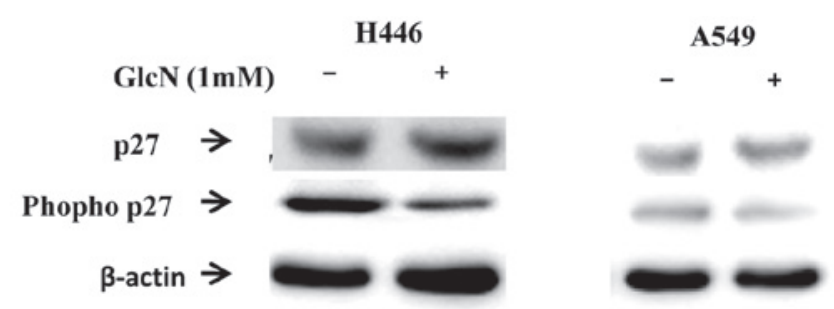

Figure 7. Effect of glucosamine on $\mathrm{p} 27^{\mathrm{Kipl}}$ protein levels and $\mathrm{p} 27^{\mathrm{Kipl}}$ phosphorylation. A549 and H446 cells were incubated with glucosamine (GlcN) for $4 \mathrm{~h}$. The $\mathrm{p} 27^{\mathrm{Kipl}}$ protein and phosphorylation levels were then detected by western blot analysis.

lation, and to simultaneously reduce cyclin E degradation. These results indicate that glucosamine inhibits G1/S transition through affecting cyclin E degradation (Fig. 6).

Glucosamine inhibits $p 27^{\text {Kipl }}$ phosphorylation at Thrl82. $\mathrm{p} 27^{\mathrm{Kip} 1}$ is one of the target proteins of Skp2 ubiquitylation, and $\mathrm{p} 27^{\mathrm{Kip} 1}$ phosphorylation at Thr182 is essential for the recognition of $\mathrm{p} 27^{\mathrm{Kip} 1}$. $\mathrm{p} 27^{\mathrm{Kip} 1}$ degradation promotes cell cycle progression into the $\mathrm{S}$ phase (16). Therefore, we detected the effect of glucosamine on $\mathrm{p} 27^{\mathrm{Kip} 1}$ expression and specific site phosphorylation. Glucosamine was found to inhibit $\mathrm{p} 27^{\mathrm{Kip} 1}$ phosphorylation and the $\mathrm{p} 27^{\mathrm{Kipl}}$ protein level was found to be upregulated in A549 and H446 cells (Fig. 7).

\section{Discussion}

Lung cancer is the leading cause of cancer-related mortality worldwide. Despite the fact that early-stage disease may be cured with surgery, recurrence rates remain high. Cell cycle abnormalities are important in tumorigenesis. In particular, shortening of the G1 phase promotes $\mathrm{S}$ phase entry in the cell cycle (12). Cyclin E and Skp2 are key factors controlling G1/S phase transition, and the overexpression of cyclin E and Skp2 induces cell proliferation (13). In the present study, we initially investigated the association of cyclin E and Skp2 levels with cell proliferation in the A549 and H446 lung cancer cell lines. Our results showed that cyclin E and Skp2 are overexpressed in these cell lines, indicating that cyclin E and Skp2 overexpression is associated with cell cycle abnormalities.

Glucosamine is a naturally occurring monosaccharide with anti-inflammatory and antitumor effects (2-5). Our results indicated that glucosamine inhibited lung cancer cell proliferation in a dose-dependent manner. In the present study, we investigated the antitumor effect of glucosamine and the underlying mechanism that regulates the G1/S checkpoint of the cell cycle. More specifically, cyclin E and Skp2 expression at the mRNA and protein levels with or without glucosamine treatment were examined. Furthermore, the suppressive effect of glucosamine on cyclin E and Skp2 expression was investigated, and our data indicated an inhibitory action of glucosamine against lung cancer cell proliferation in vitro. Cyclin E is expressed intermittently; it is accumulated in the late G1 phase and rapidly degraded in the early $\mathrm{S}$ phase. Thus, interfering with cyclin $\mathrm{E}$ degradation may affect cell cycle progression (17). The Skp2 gene is also periodically expressed throughout the cell cycle. It is low in the G0 and mid-G1 phases, then the Skp2 level increases in late G1 and remains high during the $\mathrm{S}$ phase $(18,19)$. Both Skp2 mRNA and protein levels are regulated during the cell cycle.

It is now recognized that the addition of $O$-linked $\mathrm{N}$-acetylglucosamine (O-GlcNAc) to target proteins may modulate cellular functions, including nuclear transport, transcription, cell signaling, apoptosis and cell shape (20-22). In this context, it has been shown that glucosamine inhibits ICAM-1 and MCP-1 expression by interfering with p38-MAPK and nuclear factor (NF)- $\mathrm{B}$ specific site phosphorylation $(4,5)$. The turnover of cyclin $\mathrm{E}$ is controlled by $\mathrm{SCF}^{\mathrm{Fbw}}$, and specific amino acid phosphorylation is important for its degradation level $(23,24)$. Alanine point mutation studies have shown that Thr380 and Thr62 prevent cyclin E degradation through the $\mathrm{SCF}^{\mathrm{Fbw} 7}$ pathway (25). In the present study, protein O-GlcNAc modification levels in lung cancer cell lines incubated with glucosamine were investigated, and the results obtained were consistent with expectations (data not shown). Glucosamine was able to modulate protein phosphorylation by O-GlcNAc modification of serine and threonine residues (26-28). Thus, 
we observed the specific phosphorylation site associated with cyclin $\mathrm{E}$ and $\mathrm{p} 27^{\mathrm{Kip} 1}$ degradation in the presence or absence of glucosamine. Data showed that glucosamine inhibited cyclin E Thr62 and p27 ${ }^{\mathrm{Kip} 1}$ Thr187 phosphorylation, and simultaneously reduced degradation. These results indicated that glucosamine inhibited G1/S cell cycle progression through affecting cyclin $\mathrm{E}$ degradation. Results obtained from flow cytometric analysis also demonstrated that glucosamine treatment increased the number of cells arrested in the G1 phase.

In conclusion, glucosamine may inhibit lung cancer cell proliferation by blocking cell cycle progression. The expression levels of cyclin E and Skp2, two key G1/S phase regulators, at a transcriptional (data not shown), translational and post-translational level were found to be suppressed by glucosamine. In conclusion, negative cell cycle control by cyclin E and Skp2 may constitute one of the potential underlying mechanisms via which glucosamine inhibits lung cancer cell proliferation. Further studies are required for an in-depth evaluation of the anticancer effects of glucosamine in vivo.

\section{Acknowledgements}

This study was supported by a grant from the Department of Science and Technology of Liaoning Province (20091105).

\section{References}

1. Crolle G and D'Este E: Glucosamine sulphate for the management of arthrosis: a controlled clinical investigation. Curr Med Res Opin 7: 104-109, 1980.

2. Meininger CJ, Kelly KA, Li H, Haynes TE and Wu G: Glucosamine inhibits inducible nitric oxide synthesis. Biochem Biophys Res Commun 279: 234-239, 2000.

3. Hua J, Sakamoto K and Nagaoka I: Inhibitory actions of glucosamine, a therapeutic agent for osteoarthritis, on the functions of neutrophils. J Leukoc Biol 71: 632-640, 2002.

4. Ju Y, Hua J, Sakamoto K, Ogawa H and Nagaoka I: Glucosamine, a naturally occurring amino monosaccharide modulates LL-37-induced endothelial cell activation. Int J Mol Med 22 657-662, 2008

5. Ju Y, Hua J, Sakamoto K, Ogawa H and Nagaoka I: Modulation of TNF- $\alpha$-induced endothelial cell activation by glucosamine, a naturally occurring amino monosaccharide. Int J Mol Med 22: 809-815, 2008

6. Brasky TM, Lampe JW, Slatore CG and White E: Use of glucosamine and chondroitin and lung cancer risk in the VITamins And Lifestyle (VITAL) cohort. Cancer Causes Control 22: 1333-1342, 2011.

7. Hwang MS and Baek WK: Glucosamine induces autophagic cell death through the stimulation of ER stress in human glioma cancer cells. Biochem Biophys Res Commun 399: 111-116, 2010

8. Wang Z, Liang R, Huang GS, Piao Y, Zhang YQ, Wang AQ, Dong BX, Feng JL, Yang GR and Guo Y: Glucosamine sulfate-induced apoptosis in chronic myelogenous leukemia K562 cells is associated with translocation of cathepsin D and downregulation of Bcl-xL. Apoptosis 11: 1851-1860, 2006.

9. Oh HJ, Lee JS, Song DK, Shin DH, Jang BC, Suh SI, Park JW, Suh MH and Baek WK: D-glucosamine inhibits proliferation of human cancer cells through inhibition of p70S6K. Biochem Biophis Res Commun 360: 840-845, 2007.

10. Welcker $\mathrm{M}$ and Clurman BE: FBW7 ubiquitin ligase: a tumour suppressor at the crossroads of cell division, growth and differentiation. Nat Rev Cancer 8: 83-93, 2008.
11. Nam EJ and Kim YT: Alteration of cell-cycle regulation in epithelial ovarian cancer. Int J Gynecol Cancer 18: 1169-1182, 2008.

12. Tammali R, Saxena A, Srivastava SK and Ramana KV: Aldose reductase regulates vascular smooth muscle cell proliferation by modulating G1/S phase transition of cell cycle. Endocrinology 151: 2140-2150, 2010.

13. Mittendorf EA, Liu Y, Tucker SL, McKenzie T, Qiao N, Akli S, Biernacka A, Liu Y, Meijer L, Keyomarsi K and Hunt KK: A novel interaction between HER2/neu and cyclin $\mathrm{E}$ in breast cancer. Oncogene 29: 3896-3907, 2010.

14. Kapur P, Lotan Y, King E, Kabbani W, Mitra AP, Mosbah A, Abol-Enein H, Ghoneim M and Youssef RF: Primary adenocarcinoma of the urinary bladder: value of cell cycle biomarkers Am J Clin Pathol 135: 822-830, 2011.

15. Hsieh HY, Shieh JJ, Chen CJ, Pan MY, Yang SY, Lin SC, Chang JS, Lee AY and Chang CC: Prodigiosin down-regulates SKP2 to induce p27(KIP1) stabilization and antiproliferation in human lung adenocarcinoma cells. Br J Pharmacol 166: 2095-2108, 2012.

16. Wang G, Chan CH, Gao Y and Lin HK: Novel roles of Skp2 E3 ligase in cellular senescence, cancer progression, and metastasis. Chin J Cancer 31: 169-177, 2012.

17. Lunn CL, Chrivia JC and Baldassare JJ: Activation of $\mathrm{Cdk} 2 / \mathrm{Cyclin} \mathrm{E}$ complexes is dependent on the origin of replication licensing factor Cdc6 in mammalian cells. Cell Cycle 9: 4533-4541, 2010.

18. Wei Z, Jiang X, Liu F, Qiao H, Zhou B, Zhai B, Zhang L, Zhang X, Han L, Jiang H, Krissansen GW and Sun X: Downregulation of Skp2 inhibits the growth and metastasis of gastric cancer cells in vitro and in vivo. Tumour Biol 34: 181-192, 2013.

19. Shin E, Kim SH, Jeong HY, Jang JJ and Lee K: Nuclear expression of S-phase kinase-associated protein 2 predicts poor prognosis of hepatocellular carcinoma. APMIS 120: 349-357, 2012.

20. Guinez C, Filhoulaud G, Rayah-Benhamed F, Marmier S, Dubuquoy C, Dentin R, Moldes M, Burnol AF, Yang X, Lefebvre T, Girard J and Postic C: $O$-GlcNAcylation increases ChREBP protein content and transcriptional activity in the liver. Diabetes 60: 1399-1413, 2011.

21. Carrillo LD, Froemming JA and Mahal LK: Targeted in vivo $O$-GlcNAc sensors reveal discrete compartment-specific dynamics during signal transduction. J Biol Chem 286: 6650-6658, 2011.

22. Butt AM, Khan IB, Hussain M, Idress M, Lu J and Tong Y: Role of post translational modifications and novel crosstalk between phosphorylation and $O$-beta-GlcNAc modifications in human claudin-1, -3 and -4. Mol Biol Rep 39: 1359-1369, 2012.

23. Schülein C, Eilers M and Popov N: PI3K-dependent phosphorylation of Fbw7 modulates substrate degradation and activity. FEBS Lett 585: 2151-2157, 2011.

24. Lerner M, Lundgren J, Akhoondi S, Jahn A, Ng HF, Akbari Moqadam FA, Oude Vrielink JA, Agami R, Den Boer ML, Grandér D and Sangfelt O: MiRNA-27a controls FBW7/ hCDC4-dependent cyclin E degradation and cell cycle progression. Cell Cycle 10: 2172-2183, 2011.

25. Brandt Y, Mitchell T, Wu Y and Hartley RS: Developmental downregulation of Xenopus cyclin $\mathrm{E}$ is phosphorylation and nuclear import dependent and is mediated by ubiquitination. Dev Biol 355: 65-76, 2011.

26. Yang WH, Kim JE, Nam HW, Ju JW, Kim HS, Kim YS and Cho JW: Modification of p53 with $O$-linked $N$-acetylglucosamine regulates p53 activity and stability. Nat Cell Biol 8: 1074-1083, 2006.

27. Smet-Nocca C, Broncel M, Wieruszeski JM, Tokarski C, Hanoulle X, Leroy A, Landrieu I, Rolando C, Lippens G and Hackenberger CP: Identification of $O$-GlcNAc sites within peptides of the Tau protein and their impact on phosphorylation. Mol Biosyst 7: 1420-1429, 2011.

28. Mishra S, Ande SR and Salter NW: $O$-GlcNAc modification: why so intimately associated with phosphorylation? Cell Commun Signal 9: 1, 2011. 